aD Researich ESIC № 14 Vol 14 · Segundo semestre, julio-diciembre 2016 · págs. 108 a 125

\title{
Marketing viral político dentro del esquema Ponzi
}

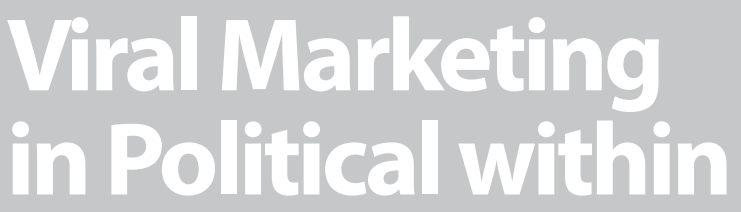

Ponzi Scheme

Eduardo Vega Fernández Doctor en Comunicación y CC.SS.

Universidad Rey Juan Carlos

www.evega.es
Vega Fernández, E. (2016)

Marketing viral político dentro del esquema Ponzi

Revista Internacional de Investigación en Comunicación aDResearch ESIC. No $14 \mathrm{Vol} 14$

Segundo semestre, Julio-Diciembre 2016 · Págs. 108 a 125 DOI: 14.7263/ADRESIC.014.005 


\section{RESUMEN}

\section{Clasificación JEL: \\ L32, H11, Z3 \\ Palabras clave:}

marketing,

viral,

subliminal,

propaganda,

política,

mentira,

engaño
En una España tan inmersa en la Globalización, o más bien Globalismo, y lejana de una autarquía económica de aquellas largas décadas del siglo XX, no paramos de darle una gran importancia a la publicidad y al marketing comercial, cuando es más que importante concebir la magnitud de la propaganda y comunicación política. El comercio y las multinacionales nos ofertan productos visibles, tangibles, y posiblemente perceptibles por los otros tres sentidos. Sin embargo la política nos presenta unas propuestas que no se pueden percibir de la misma forma que en el comercio, dejando lejanos a los ciudadanos de las decisiones sobre la materia política, de su completa comprensión y entendimiento sobre su desarrollo, y su por qué. Un producto y una marca comercial nos pueden despertar una completa indiferencia y prescindibilidad, pero la política y la economía son aspectos de gran importancia en nuestras vidas. Aunque nos sea indiferente, van a marcar nuestro futuro. Será lo que nos facilite o imposibilite tener un empleo, abrir un negocio, disponer de sanidad y educación, seguridad ciudadana, administración pública y un largo etcétera de asuntos imprescindibles de nuestras vidas.

Es por ello más que importante tomar nuestras decisiones en este terreno, alejarnos de la mentira, la embaucación, la información parcial e incompleta de los media, así como de falsas verdades. Es imprescindible concebir este nuevo concepto del marketing viral político dentro del esquema

Ponzi que posibilita potenciar una mentira que mantenga una agrupación y a su representante al frente del gobierno, destruyendo las perspectivas socioeconómicas y políticas en las que habíamos confiado. Ponzi encumbra a un líder y su agrupación política al poder, gracias al virus difundido inconscientemente por la vox populi, creando una pirámide popular que se derrumbará cuando descubra el pueblo la mentira propagandística difundida sobre ese producto político que ha acabado convirtiéndose en un nuevo gobierno inamovible de su posición.

\section{JEL Classification: \\ L32, H11, Z3 \\ Key words:}

marketing,

viral,

subliminal,

propaganda,

politics,

lie,

fraud.
In a Spain so immersed in Globalization, or rather Globalism, and far from economic autarchy of those long decades of the twentieth century, we are not giving importance to advertising and marketing, when it is more than important to conceive the magnitude of propaganda and political communication. Businesses and multinationals offer us visible, tangible products. However, nowadays, politics presents proposals that cannot be perceived in the same way as in trade, leaving the citizens far from these political decisions, their complete comprehension and understanding of their development and its reason why. A product and a trademark can spark a complete indifference and dispensability in people, but politics and the economy are issues of great importance in our lives. Although we are indifferent, they still mark our future. This fact will be the one that provides us with a job, allows us to start a business, provides health and education, public safety, public administration and a long list of essential issues of our lives.

It is therefore more than important for us to make decisions in this area, away from lying, partial and incomplete information from the media, nor false truths. It is essential to conceive this new concept of political viral marketing within the Ponzi scheme, which enables a lie to be promoted to keep a party and its representative in government office, destroying the socioeconomic and political perspectives that we had trusted. Ponzi praises a leader and his political group in power, thanks to the virus unknowingly released by the vox populi, creating a popular pyramid that will fall when people discover the propaganda and lies disseminated about this political product that has ended up becoming a new immovable government of position. 


\section{Introducción}

Es más que común oír críticas a la existencia de un sistema piramidal socioeconómico y de clases. La crítica común a este concepto es que existe una pirámide en las sociedades capitalistas, gracias a la cual se benefician unos pocos que están en el último escalón de una pirámide que se sostiene por otros escalones de los que forman parte otros sectores socioeconómicos, políticos o sociales que tienen menos poder económico, político y social que los que están encima, hasta que se llega a una base de la pirámide que es sostenida por las clases más bajas que sirven a los que tienen encima. En primer lugar es más que importante destacar que este sistema piramidal no se sostiene únicamente en las sociedades $100 \%$ capitalistas, como EE.UU., sino que cualquier régimen político del mundo es piramidal. En segundo lugar es necesario añadir que la seguridad social que existe en sociedades capitalistas mixtas como la europea es también piramidal, puesto que quien recibe un subsidio por desempleo lo están recibiendo de quienes trabajan, sean cuales sean sus necesidades, y quienes reciben el pago por sus jubilaciones o prejubilaciones lo están recibiendo por parte de quienes se encuentran todavía en su etapa laboral, al igual que los primeros fueron quienes facilitaron sostener a sus predecesores pensionistas. Así los nuevos inversores satisfacen las inversiones de los antiguos inversores. Otra extensión más que importante del sistema piramidal son las dictaduras comunistas, aquellas que han tenido una etapa más duradera que sus grandes rivales ideológicos, pero cercanos regímenes fascistas o nacional-catolicistas ${ }^{1}$. El motivo por el que incluyo los regímenes comunistas es debido a que por

1 Gallego, F.y Morente, F. (2005). El fascismo en España. Barcelona: Intervención cultural. encontrarse muy lejanos a la herencia teórica ${ }^{2}$ que dejó su mentor -Karl Marx- consistían en un dictador que estaba en lo alto de la pirámide, con unos pocos ministros debajo de él, seguidos por los dirigentes de la industria, del sindicato único, y pocas instituciones más en el siguiente escalón, y mantenidos todos ellos por el último gran escalón de la masa popular. El comunismo y el fascismo han sido, por ello, sistemas totalitarios mantenidos por un gran sistema piramidal ${ }^{3}$.

Al margen de todo lo anterior el auténtico sistema piramidal que perjudica a todos sus componentes, excepto al líder de la pirámide, es el Esquema Ponzi. Aunque se haya declarado rotundamente ilegal en Estados Unidos y Europa, aún se han desvertebrado recientes sociedades que desarrollaban dichos esquemas en el s.XXI, incluso en España.

\section{Marketing viral}

Mucha gente ha defendido que la mejor publicidad es el boca a boca, por lo que los publicistas y los profesionales del marketing no podían dejar de lado este aspecto de gran relevancia. En 1996, Douglas Rushkoff —profesor de la Universidad de Nueva York- argumentó y defendió que si un mensaje con determinados aspectos llega a un destinatario interesado, éste quedará infectado del mensaje y difundirá la idea como un virus ante otros usuarios, quienes una vez infectados continuarán difundiendo el virus comunicativo de una manera excepcional ${ }^{4}$. El objetivo común de toda campaña de marketing viral es «la creación de una corriente epidemio-

\footnotetext{
2 Ferrer, A. (2010). Marx. Leyendo el manifiesto del partido comunista (1848). Valencia: PUV.

3 Ohanian, P.C. (2010). La cuestión armenia y las relaciones internacionales. Buenos Aires: Akian.

4 Sivera, S. (2008). Marketing viral. Barcelona: Editorial UOC.
} 
lógica en dónde el mensaje es el centro de atención» (Del Pino, 2007:68).

El marketing viral, o marketing vírico en Hispanoamérica, comenzó a desarrollarse principalmente en Internet a través del correo electrónico y más tarde en las redes sociales, en combinación con el 2.0, convirtiéndose así en la versión mercadotécnica internauta del boca a boca ${ }^{5}$. El primer uso conocido del viral lo desarrolló Microsoft en 1999, cuando Hotmail llegó a los 12 millones de usuarios en tan solo 18 meses gracias a sus modernas técnicas de marketing en las que conseguía que los internautas se convirtieran en recomendadores de la marca cuando enviaban e-mails a sus amigos y familiares con la posdata: «consigue tu correo electrónico gratuito con Hotmail».

Sumémosle a esto que cada mail contenía al final el logotipo de Microsoft ${ }^{6}$.

Es más que importante destacar que el nuevo marketing 2.0 que se enfoca a los usuarios de las redes sociales ${ }^{7}$ tiene frecuentemente una innegable combinación con el marketing viral. Un reciente ejemplo de ello ha sido el fenómeno Movember. Esta idea de la contracción de moustache y november surgió en 2003 de un grupo de jóvenes australianos que tenían un amigo que padecía cáncer de próstata. En 2004 se impulsó la Fundación Movember, que tenía por objetivo recoger donativos para investigaciones frente al cáncer de próstata y de testículos ${ }^{8}$. A lo largo de los años se comenzó a desarrollar un marketing viral 2.0 que facilitase la expansión de los donantes que se unían a

\footnotetext{
5 Montañés, M.A. (2014). Técnicas de Marketing viral . Madrid. Esic.

6 Kotler, P. (2003). Fundamentos de marketing. México D.F: Prentice Hall.

7 Alonso, M.A. y Adell, A. (2011). Marketing político 2.0. Barcelona: Planeta.

8 Luengo, M. «¿A dónde va a parar el dinero de Movember?». El País, p. 17, no 13.647, 12 de noviembre de 2014
}

la causa. Así es como en 2004 comenzó su desarrollo en su web oficial, extendiéndose en 2010 hasta las redes sociales y haciéndose mundialmente famoso en 2014, gracias a los 21 países que apoyaban la causa de la Fundación Movember. Si desarrollamos un análisis sociológico y marketiniano, el fenómeno Movember consiguió hacerse famoso y recibir apoyos de particulares y famosos de todo el mundo gracias a la aplicación viral del 2.0 que desarrollaron a través redes sociales como facebook. La idea era que diversos grupos de amigos de todo el mundo creasen su propio grupo en la web oficial de Movember, que funcionaba como red social durante el mes de noviembre, en la que los usuarios hacían sus propias donaciones a la causa. A partir de ahí, los propios miembros de cada grupo desarrollaban un 2.0 a través de facebook en el que invitaban a sus amigos o conocidos a unirse a su grupo o hacer una donación al mismo. Si a este 2.0 le sumamos que la gente de la calle les preguntaría por qué llevaban bigote, si no está de moda, ellos le responderían el motivo, uniéndose más gente a Movember o anunciándolo a más gente a través del boca a boca, la gran herramienta del marketing viral. Las técnicas propagandísticas, y no publicitarias, de Movember hicieron posible que en 11 años se donaran 400 millones de euros que se emplearon para hacer posibles casi 800 investigaciones en beneficio de la salud del varón. La Fundación Movember ha conseguido que incluso grandes deportistas o artistas, como Iker Casillas y Kylie Minogue, apoyaran la causa hasta tal punto de convertirse en embajadores de la misma gracias al gran efecto viral de Movember. ${ }^{9}$

9 Amil, G. «Mostachos solidarios». Diario de Sevilla, p. 17, no 9.724, 20 de noviembre de 2013. 


\section{Marketing multinivel, esquema piramidal y esquema Ponzi}

Un error muy común en España es plantear la sinonimia entre un esquema piramidal y un esquema Ponzi, cuando en realidad son dos conceptos cercanos con grandes rasgos que presentan heterogeneidad. Es imprescindible destacar que el marketing multinivel no exige una inversión económica a la empresa, lo que hace legal el MLM en la mayoría de los países. ${ }^{10}$ El sistema piramidal y el esquema Ponzi exigen una inversión financiera a sus miembros que es bastante fácil que no vuelvan a ver a partir del momento en el que la empresa se declare en bancarrota y sus dirigentes o accionistas están encarcelados u ocultos en otros países. Tanto el MLM como los esquemas piramidales y Ponzi se nutren fundamentalmente de una aplicación directa del marketing viral. Los participantes en el MLM y el esquema piramidal requieren de nuevos inversores para generar sus propios ingresos, lo que significa una aplicación viral del proyecto. El esquema Ponzi no exige la creación de una pirámide de referidos apadrinados por los nuevos afiliados que invierten en la empresa, pero les es presentado tan maravilloso a sus usuarios que no cesarán en comentar a sus allegados cómo les ha cambiado la vida participar en una inversión Ponzi.

\section{Marketing multinivel}

En el comercio tradicional la empresa paga a sus trabajadores un salario por la venta de los ByS que oferta la empresa. La mercadotecnia entre niveles ${ }^{11}$ recibe este nombre porque se basa en aquellas empresas para las que lo más importante no es vender al cliente final, sino lograr y ges-

10 Licciardello, S. (2001). MLM Success secrets. Nueva York: Routledge.

11 Reyes, R. y Munch, L. (2012). Comunicación y mercadotecnia politica. México D.F: Noriega tionar una red de agentes que les permitan ganar más dinero por ventas a través de las comisiones porcentuales obtenidas gracias a la red de vendedores que el agente tiene a su cargo, quienes obtendrán también pequeñas comisiones por venta. Para ello es imprescindible la creación de redes relacionales de diferentes niveles de venta que sean fortalecidas por las relaciones interpersonales entre los distribuidores que componen el sistema multinivel. ${ }^{12}$ Cada uno de los agentes de una empresa que desarrolla el marketing multinivel se esfuerza por la venta de los productos de la empresa a la que representa, obteniendo un beneficio porcentual de la cuantía económica obtenida por la empresa con la venta del producto gracias a su representante. La empresa premia a sus representantes con un porcentaje de los ingresos obtenidos gracias a la venta del producto. Este esquema multinivel permite a los agentes convencer a otras personas a formar parte de la empresa como representantes. El nuevo representante es apadrinado por el agente que le invita a unirse al proyecto, por lo que también recibirá una parte porcentual de las ventas de sus referidos que ha apadrinado en nombre de la empresa. ${ }^{13}$

El MLM comenzó a ser un sector emergente en España durante los años 90, en especial tras la aprobación de la Ley de Ordenación del Comercio Minorista en $1996^{14}$, aunque contaba con el riesgo de no ser más que un fraude piramidal $^{15}$. La idea era hablar del negocio con todo el mundo, usando como herramienta principal

12 Ongallo, C. (2012). Otros campos de la venta directa. Madrid: Díaz de Santos

13 Licciardello, S. (2001). MLM Success secrets. Nueva York: Routledge.

14 Ongallo, C. (2007). El libro de la venta directa. Madrid: Díaz de Santos

15 Clothier, P. (1991). Marketing multinivel. El negocio de los 90 . Valencia: Jumerca. 
de captación el propio éxito en el negocio para la captación de nuevos inversores y ampliando la propuesta mediante la fijación de metas ${ }^{16}$.

Actualmente ha habido una evolución del Marketing Multinivel hacia un nuevo Marketing en Red que supone la aplicación y el desarrollo del MLM por Internet, buscando nuevos afiliados que estén dispuestos a formar parte de la red creada por cada uno de los participantes del esquema multinivel de una empresa. Un nuevo concepto conocido como Network Marketing ${ }^{17}$ que ha permitido la creación de nuevas polémicas empresas digitales como LibertàGià que solo permite el registro a través de la invitación de un padrino que ya esté participando como afiliado. Promete a sus usuarios grandes beneficios viendo publicidad y creando una red de afiliados de la que obtendrán un porcentaje de sus beneficios. No exige inversión económica alguna, pero es una embajada del esquema piramidal dentro del MLM. Está empresa está ubicada en el Parque de las Naciones de Lisboa, pero ya está siendo criticada por sus propios usuarios que la acusan de no haber recibido ningún pago, quienes ya llegan a calificarla como scam o fraude.

\section{Esquema piramidal}

Es importante destacar que tanto el MLM como el esquema piramidal presentan una estructura piramidal. El negocio piramidal, a diferencia del multinivel, se basa en el engaño. No hay un producto real, sino uno subyacente que justifica mediante estrategias sicofantas un modelo de negocio empresarial basado en la estrategia de recircular el dinero. Un representante de la empresa no se encarga de vender un producto al

\footnotetext{
16 Bruno, G. (2002). Marketing multinivel 3x. Roma: Bruno Editore.

17 Schuster, G. (2010). Network marketing. Nordersted (Alemania): Grin.
}

usuario final como en el MLM. Centra sus objetivos únicamente en reclutar más personas que a su vez recluten a otras que confíen en la empresa y donen su dinero como inversión en ese supuesto producto que la empresa asegura que incrementará su valor, lo que facilitará un retorno completo de su inversión acompañado de unos intereses que pagará la empresa a cada inversor que haya sido reclutado por el inversionista que le había propuesto la idea.

La empresa asegura altas rentabilidades en un corto periodo de tiempo. Los primeros inversores pueden obtener un beneficio gracias al reclutamiento de una serie de afiliados, pero con el crecimiento de la pirámide es necesario ofertar unos intereses o beneficios menores para los siguientes inversores hasta que el escepticismo de los posibles siguientes inversores se convierta en rechazo. Esto hará que la empresa se declare en bancarrota y deje a la mayoría de los afiliados que conforman la pirámide sin los ahorros o el dinero obtenido en hipotecas bancarias que han empleado para invertir en el negocio fraudulento en el que habían confiado su dinero.

La venta piramidal difiere ampliamente del MLM por ser una venta fraudulenta expresamente prohibida tanto en la U.E. como en los EE.UU. El problema se basa en que ambos sistemas presentan una delgada línea roja casi invisible que dificulta conocer la veracidad del modelo de negocio planteado por la empresa ${ }^{18}$. El hecho de que ambas se nutran intencionadamente del Marketing Viral por parte de los agentes o representantes de la empresa que luchan por reclutar nuevos afiliados hace más compleja su diferenciación para quien es invitado a participar en el esquema.

18 García, M.D. (2004). Marketing multinivel. Madrid: Esic. 


\section{- Esquema Ponzi}

La pirámide tradicional exige a sus inversores que recluten a un determinado número de personas a la causa empresarial, de donde obtendrá el dinero la empresa para pagar a los inversores anteriores sus intereses, creando una pirámide que se debilitará en el momento que carezca de nuevos inversores, dejando sin su dinero a los viejos inversionistas.

El esquema Ponzi no exige la captación de nuevos inversores por parte de los anteriores afiliados que han invertido su dinero. Ponzi se nutre de nuevos inversores que invierten sus ahorros en la empresa. Los nuevos afiliados han confiado en lo que les comentaron sus allegados sobre el éxito en la inversión. Este será el momento en el que puedan cobrar sus beneficios los viejos inversionistas. Es difícil de detectar una estafa Ponzi porque el esquema no es ofertado de una forma piramidal que exige de primera mano al inversor que reclute a un determinado número de personas para que reciban los intereses.

Un famoso y reciente ejemplo de la aplicación del esquema Ponzi es el que desarrolló Bernard Madoff desde 1960 hasta que fue destapado el fraude en $2008^{19}$, momento en el que los inversores, asustados por la crisis económica global decidieron retirar sus inversiones en Madoff, y se descompuso la pirámide ${ }^{20}$.

\section{Esquema Ponzi Origen y evolución}

Este esquema hace honor a su inventor, Carlo Ponzi, quien se considera uno de los mayores estafadores de todos los tiempos. Este joven italiano de bajos recursos emigró hacia América en

19 Sander, P.J. (2009). Madoff. Plymouth: Lyons Press.

20 Arvedlund, E (2009). Madoff. The man who stole $\$ 65$ billion. London: Penguin group.
1903, con tan solo 21 años. Comenzó su andadura transoceánica en Canadá, donde tras haber sido imputado en 1908 como un estafador de poca monta decidió mudarse a Boston (Estados Unidos) para ampliar su negocio a mayor escala, empleando los conocimientos en el mundo de la estafa que había desarrollado en Canadá. Más tarde recibió un correo de Italia que le decía que los cupones extranjeros de respuesta internacional de correos se podían vender más caros en los EE.UU. ${ }^{21}$ Así comenzó a comerciar con cupones que obtenía por 1 centavo en España y que tenían un valor de 6 centavos de franqueo en Estados Unidos, como una inversión filatélica. Era una inversión tan jugosa que procedió a solicitar nuevos los inversores que participaran en esta oportunidad, prometiendo rendimientos de aproximadamente el $50 \%$ en 45 días $^{22}$. Este fue uno de los primeros ejemplos de marketing viral multinivel, ya que la noticia corría como la pólvora e incluso el propio Ponzi contrató unos agentes que recibirían comisiones por cada nuevo inversionista.

En realidad Ponzi había creado una sociedad fantasma en la que los inversores recuperaban sus ingresos con amplios beneficios gracias al dinero invertido por las siguientes víctimas. Es evidente que un sistema como este solo funciona cuando hay nuevos inversores que sufragan los gastos de los anteriores y les proporcionan un beneficio económico, al igual que ellos recibirán de los siguientes inversionistas, por lo que no se cansaban a de convencer a terceros en confiar en esta oportunidad ${ }^{23}$. Carlo Ponzi disponía de una vida repleta de lujos y era reconocido como un

21 Connolly, M. (2007). International business finance. Nueva York: Routledge.

22 Teall, J. (2013). Financial trading and investment. Oxford: Academic Press.

23 Kiyosaki, R. (2012). La ventaja del ganador. Madrid: Aguilar. 
gran empresario. El problema se dio cuando la gente comenzó a desconfiar de su sistema empresarial, por lo que carecía de nuevos inversores y los recientes inversionistas reclamaban su inversión, momento a partir del cual se desmembraría el esquema, exceptuando a su fundador. Su esquema piramidal se había deshecho cuando se supo que tales cupones no existían y que la única forma de la obtenían ingresos los inversionistas era a través de las próximas víctimas que confiaban en la palabra de Carlo Ponzi ${ }^{24}$. Fue encarcelado, pero tras su liberación trató de emplear el mismo esquema en inversiones inmobiliarias en Florida y fracasó 25 . Finalmente fue deportado a Italia, donde se convirtió en el asesor financiero de Benito Mussolini, pero fue expulsado rápidamente del Gobierno y del Partido Nacional Fascista, ante lo que huyó a Brasil, donde falleció de un ataque al corazón en 1948 en una casa de beneficiencia ${ }^{26}$.

Finalizando la perspectiva comercial del Esquema Ponzi, es más que importante destacar tres casos recientes en España de este tipo de estafa piramidal: Gescartera (2001), Afinsa y Fórum Filatélico (2006) ${ }^{27}$.

\section{Goebbels y el marketing político}

A lo largo de la historia se ha investigado mucho sobre el nazismo y Adolf Hitler, habiéndose desarrollado una infinidad de investigaciones, novelas, películas y documentales sobre la materia. Sin embargo, hay un personaje de gran transcendencia en el nazismo y la propaganda que ha

\footnotetext{
24 García, M.D. (2004). Marketing multinivel. Madrid: Esic.

25 García, J. (2008). De la quimera inmobiliaria al colapso financiero. Barcelona: Bosch.

26 Rothberg, M. (2010). American Greed. Bloomington: Author House.

27 García, M.C. (2014). Nuevas perspectivas del tratamiento jurídico de la discapacidad y la dependencia. Madrid: Dykinson.
}

sido dejado de lado cuantiosas veces: Joseph Goebbels.

Diversos autores e investigadores de gran reputación coinciden en nombrar a Nicolás Maquiavelo el padre de las ciencias políticas modernas. Este fiorentino de principios de la Edad Moderna relató en El Príncipe una serie de frases que Maquiavelo redactó para «el que no sabe», entendiéndose así que hay una clara identidad entre el «príncipe» de Maquiavelo y los estados modernos de la sociedad contemporánea occidental. En ambos casos se entiende que tanto el bien y el mal, como lo justo y lo injusto, lo útil y lo inútil se expresan en relación al poder político y a su capacidad para cumplir su fin ${ }^{28}$. Según Gramsci (1949), Maquiavelo «enseña al pueblo que quien quiere los fines debe también querer los medios apropiados para conseguirlos, incluso si estos medios pueden parecer en contra de la ideología del momento, con la religión, etc. ${ }^{29}$

Un ejemplo reciente de ello sería una pequeña modificación parcial de la Ley del Aborto (2014) por parte del Gobierno de Mariano Rajoy, a pesar de que el Partido Popular no paró de negar su aprobación y pedir su abolición en beneficio de los sectores más conservadores y católicos de la sociedad, durante sus años en la oposición, como una estrategia de persuasión. Otro ejemplo no tan lejano sería la retirada de las tropas españolas de Iraq (2004) por parte del Ejecutivo de José Luis Rodríguez Zapatero, a cambio de reenviarlas a Afganistán (2009), Líbano (2006) y Libia (2011).

«Otrora tras la pancarta del no a la guerra, no a la guerra de Iraq, más tarde con el sí pero a la

28 Bermudo, J.M. (1994). Maquiavelo, consejero de príncipes. Barcelona: Universidad de Barcelona.

29 Gramsci, A. (1979). Note sul Machiavelli, sulla política, e sullo stato moderno. Milán: Einaudi. 
guerra de Afganistán y ahora encabezando la coalición de París, rememorándonos a todos otra coalición: la coalición de las Azores» (Llamazares, 2011).

\section{1 principios de propaganda}

Es evidente que todo autor tiene sus predecesores y sus sucesores. Al igual que Maquiavelo es considerado el padre de las ciencias políticas, Goebbels es considerado su sucesor paternal del terreno propagandístico. Este astuto y taimado ministro de propaganda desarrolló los siguientes principios de propaganda política que actual que consciente o inconscientemente se han continuado aplicando en la propaganda o marketing político moderno de los estados democráticos contemporáneos:

1) De simplificación y del enemigo único. Adoptar una única idea, un único símbolo. Individualizar al adversario en un único enemigo.

Si para los nazis fueron los judíos dentro de su xenofobia política radical, en 2012 Cristina Fernández trataba de esconder la insaciable crisis ante el pueblo argentino, mediante la acusación de la misma a las multinacionales extranjeras y principalmente a Repsol como potenciador de la misma por poseer YPF como filial.

2) Del método de contagio. Reunir diversos adversarios en una sola categoría o individuo. Los adversarios han de constituirse en suma individualizada.

En 2014 sería Pablo Iglesias -Podemos- en «la casta» donde reuniría diversos adversarios en una suma individualizada, mediante el contagio de la pequeña cercanía entre unos y otros: franquistas, conservadores, Iglesia, derecha, populares y empresarios.
3) De la transposición. Cargar sobre el adversario los propios errores o defectos, respondiendo el ataque con el ataque. «Si no puedes negar las malas noticias, inventa otras que las distraigan».

El Partido Popular trató de limpiar su imagen pública que había sido mancillada por el caso de los papeles de Bárcenas y su más que conocida corrupción, mediante la orden de inspeccionar todos los vehículos que salen de Gibraltar para evitar el tráfico de tabaco procedente del Peñón y que siga habiendo españoles con su empresa registrada en Gibraltar, defraudando así a la Hacienda Pública y gozando de la Seguridad Social española. Todo esto se desarrolló un año más tarde de que la Royal Navy británica instigara a las patrulleras de la Guardia Civil y a los pescadores gaditanos en aguas españolas. Una estrategia bastante precisa para que la vox populi se dedique a discutir sobre el Peñón y no sobre el ex tesorero del PP.

4) Principio de la exageración y desfiguración. Convertir cualquier anécdota, por pequeña que sea, en amenaza grave.

«El régimen iraquí posee armas de destrucción masiva» (Aznar, 2002).

5) De la vulgarización. Toda propaganda debe ser popular, adaptando su nivel al menos inteligente de los individuos a los que va dirigida. Cuanto más grande sea la masa a convencer, más pequeño ha de ser el esfuerzo mental a realizar. La capacidad receptiva de las masas es limitada y su comprensión escasa; además, tienen gran facilidad para olvidar.

«No a la guerra» (Zapatero, 2003).

6) De orquestación. La propaganda debe limitarse a un número pequeño de ideas y repetirlas incansablemente, presentarlas una y otra vez 
desde diferentes perspectivas, pero siempre convergiendo sobre el mismo concepto. Sin fisuras ni dudas. De aquí viene también la famosa frase: «Si una mentira se repite suficientemente, acaba por convertirse en verdad».

El «no a la guerra» de Zapatero significó retirar las tropas de Afganistán para reenviarlas a Afganistán (2009), Líbano (2006) y Libia (2011).

7) De renovación. Hay que emitir constantemente informaciones y argumentos nuevos a un ritmo tal que, cuando el adversario responda, el público esté ya interesado en otra cosa. Las respuestas del adversario nunca han de poder contrarrestar el nivel creciente de acusaciones.

Este es un principio propagandístico muy empleado por Pablo Iglesias cada vez que le preguntan algo que le puede perjudicar públicamente ante los mass media y el electorado si llega a responder lo que le cuestionan.

Un famoso ejemplo de ello es la discusión entre Iglesias y Esperanza Aguirre en La Sexta Noche el 26 de julio de 2014, cuando Iglesias evade constantemente con acusaciones la acusación interrogativa de Aguirre sobre ETA:

- Lo importante aquí es saber, Pablo Iglesias, qué opina. ¿Está contra ETA? Pues que lo repita conmigo. Los etarras son unos asesinos. Vamos don Pablo, no se ría. Dígame. Los etarras son asesinos. Repita conmigo.

- Señora Aguirre, a mi no me toma la lección nadie. Mientras usted hable, no le voy a interrumpir, pero ahora le voy a hacer yo alguna pregunta, porque parece que a usted no le gusta responder a preguntas. Parece que usted está muy preocupada por esto de los Derechos Humanos. Su primer viaje oficial fue a China, ¿verdad? Un país denunciado sistemáticamente por Amnistía Internacional. En
2013 el Partido Popular firmó un acuerdo de amistad con el Partido Comunista de China. ¿Ha preguntado usted a Rajoy por esto? Quería preguntarle también por otra cosa, a usted que le preocupan tanto las dictaduras. ¿Qué opina usted de su amigo Villar Mir? Imputado, por cierto, que tiene negocios en una dictadura como Arabia Saudí. Repita conmigo señora Aguirre. Villar Mir, está muy mal hacer negocios con dictaduras. Repita.

- Él no quiere que yo le tome la lección, pero me la quiere tomar él a mí, por lo que se ve. Yo estoy en contra de todas las dictaduras, querido Pablo. Me gustaría que tú también estuvieras en contra de todas las dictaduras. ¿Podrías repetir conmigo? Los etarras son asesinos. Los Castro son dictadores.

- Repita usted conmigo, señora Aguirre. La trama Gurtel firmó más de 200 contratos con el Gobierno que yo presidía, mientras yo era Presidenta. A ver, repita.

- Es totalmente cierto, y yo lo lamento. Y mire usted. Nadie, ninguna institución, ni siquiera Podemos, ya lo verá usted, está libre de que en su seno aparezcan personas corruptas ${ }^{30}$.

Al final Pablo Iglesias consiguió «emitir constantemente informaciones y argumentos nuevos a un ritmo tal que, cuando el adversario responda, el público esté ya interesado en otra cosa, de una forma que las respuestas del adversario nunca han de poder contrarrestar el nivel creciente de acusaciones» y nunca hizo crítica alguna al terrorismo etarra.

8) De la verosimilitud. Construir argumentos a partir de fuentes diversas, a través de los llama-

30 La Sexta Noche. Presentador: Iñaki López. La Sexta . 24 de ju lio de 2006. 
dos globos sondas o de informaciones fragmentarias.

Empleado todos los años en el Debate sobre el Estado de la Nación, cuando todos los grupos políticos del Congreso se lanzan acusaciones fragmentarias construidas a partir de fuentes diversas.

9) De la silenciación. Acallar las cuestiones sobre las que no se tienen argumentos y disimular las noticias que favorecen el adversario, también contraprogramando con la ayuda de medios de comunicación afines.

La misma trifulca dialéctica de Iglesias con Aguirre se puede reflejar perfectamente como ejemplo de este principio, no solo por «disimular las noticias que favorecen al adversario» sobre la visita a una Heriko Taberna de Iglesias y su aceptación de la liberación de los presos de ETA, sino porque el debate se produce en La Sexta. La importancia que le doy a este medio de comunicación es debido a que sea el más laico, progresista y republicanista, no solo durante su etapa dentro de Mediapro, sino incluso tras la compra de La Sexta por parte de A3 Media sigue manteniendo su tendencia política para no perder audiencia. De esta forma Iglesias está «contraprogramando con la ayuda de medios de comunicación afines».

10) De la transfusión. Por regla general, la propaganda opera siempre a partir de un sustrato preexistente, ya sea una mitología nacional o un complejo de odios y prejuicios tradicionales. Se trata de difundir argumentos que puedan arraigar en actitudes primitivas.

«227 años del nacimiento del Padre Bolivar, día de júbilo para la patria toda y no sólo para Venezuela sino para la patria grande, para estos pueblos de nuestra América que 200 años después de iniciada la revolución de independencia por estos días hace 200 años, hoy igual que ayer siguen luchando, siguen batallando por esa plena independencia y por la creación de la patria humana, de la patria grande, de la patria nueva» (Chávez, 2010) ${ }^{31}$.

11) De la unanimidad. Llegar a convencer a mucha gente de que piensa «como todo el mundo», creando una falsa impresión de unanimidad.

El slogan propagandístico del Partido Popular de cara a las Generales de 2011:

«Súmate al cambio». El slogan de «el cambio» ha sido empleado en España desde las Generales de 1981, pero en este caso tratan de convencer al ciudadano de que se unan a quienes desean y el cambio, planteándole que el único cambio posible es el PP, creando así «una falsa impresión de unanimidad».

Hemos de entender que la etapa de entreguerras en la que Goebbels desarrolló estos 11 principios de propaganda, la sociedad era una masa general bastante compacta y de difícil división en segmentos de estudio sociológico, político o de mercado, y con un bajo nivel cultural o de estudios en comparación con la época actual, lo que facilitaba a los grupos políticos la idea de emitir un mensaje general que satisfaga la demanda popular de un grupo político, con su respectiva competencia entre los partidos políticos. Era, por tanto, más difícil la idea de hacer una división en diferentes nichos pequeños de opinión política, simplificándose a una masa común y homogénea. Ello suponía que «cuanto más grande sea la masa a convencer, más pequeño ha de ser el esfuerzo mental a realizar» y sig-

31 http://www.vive.gob.ve/blogs/frases -de-ch\%C3\%A1vez/discurso-del-presidente-de-la-rep\%C3\%BAblica-bolivariana-de-venezuelahugo-ch\%C3\%A1vez (Sistema Bolivariano de Comunicación e Información). 
nificaba que los partidos podían desarrollar unas estrategias de penetración ${ }^{32}$ enfocadas al mercado electoral, emitiendo una propaganda populista, e incluso demagoga, que capte grandes grupos del electorado. Por aquellas fechas no existía el marketing viral, pero ha sido uno de sus grandes predecesores, haciendo incluso que sea posible que «si una mentira se repite suficientemente, acaba por convertirse en verdad» gracias al poder viral de la vox populi en el boca a boca.

\section{Marketing político viral subliminal}

Es bastante conocido que la publicidad subliminal es una disciplina que manipula al individuo con mensajes ocultos que no sabe que ha recibi$\mathrm{do}^{33}$. A pesar de que el receptor no sea consciente de la recepción de un mensaje subliminal, este tiene una perfecta capacidad para influir en su conducta incitándole a comprar una marca, convertirse en seguidor o adepto de alguna idea o agrupación. La publicidad subliminal puede definirse como aquella que funciona a nivel subconsciente (O'Guinn, Allen y Semenik, 1999)34 sobre la recepción del individuo. Es una técnica publicitaria completamente ilegal, pero es difícil de demostrar su praxis por ser un mensaje oculto difícil de localizar conscientemente. Pero también existe la propaganda subliminal.

Un reciente ejemplo del marketing político viral subliminal se ha desarrollado el pasado año 2014, en pleno mundial de fútbol, en beneficio de dos grupos e identidades políticas ampliamente antagonistas. Ante la interpretación popular de la bandera rojigualda como símbolo del franquismo, don Juan Carlos no pudo escoger

32 Munuera, J.L. y Rodríguez, A.I. (2007). Estrategias de marketing. Madrid: Esic.

33 Rivera, J. y Sutil, L. (2004). Marketing y publicidad subliminal. Madrid: Esic.

34 García-Uceda, M. (2011). Las claves de la publicidad. Madrid: Esic. una fecha mejor para su abdicación que el 1 de junio de 2014, así como la coronación de Felipe VI el posterior 19 de junio. Conscientes que habría múltiples manifestaciones públicas en todas las plazas de España parapetadas bajo la tricolor en defensa de una república parlamentaria que de libertad al ciudadano de elegir ante sufragio quien será el presidente de la República en substitución del jefe del Estado, los reyes aprovecharon el Mundial para hacer un marketing viral desde una perspectiva freudiana gracias al Mundial de fútbol. Entendiendo que la concepción española de la Selección no significa la difusión de un mensaje como un virus, sino incluso como una epidemia mediática y popular, con España entera con la camiseta de la roja, con la bandera española en el balcón, o plantada frente al televisor para ver los partidos de España durante el mismo momento que banderas rojigualdas ondean al viento dentro de los estadios en los que compite el equipo nacional.

Aunque parezca mentira, Pablo Iglesias tampoco quiso hacer oídos sordos a esta gran oportunidad. Antes de que España venciera a Alemania en la final y ganase la Eurocopa -2008- se creó una canción de homenaje a la Selección que rezaba «Podemos, podemos, podemos sí». Esto se convirtió en un canto popular de cara al Mundial de 2010 y la Eurocopa de 2012, en las que España sería de nuevo la campeona absoluta. Aprovechando que la primera participación electoral de la agrupación dirigida por Iglesias sería en las europeas que se celebraban poco antes del Mundial de 2014, no dejaron de lado la oportunidad de llamar a su partido Podemos. Aunque no podían convertirlo en un himno oficial del partido por derechos de autor, sabían que se cantaría de nuevo en el Mundial y que los principales votantes de Podemos serían los jóve- 
nes, quienes son a la misma vez los mayores usuarios de Internet y Youtube. Lo que facilitaría que estuvieran escuchando todo el tiempo el «podemos, podemos, podemos sí», una y otra vez, inconscientes del gran poder subliminal inintencionado del mensaje $e^{35}$.

\section{Aplicación del esquema Ponzi en el marketing viral}

Es importante destacar que en el marketing viral, ya sea comercial o político, los principales difusores del mensaje son los propios ciudadanos que reciben un mensaje que les impacta y lo repiten constantemente entre sus allegados, quienes continuarán difundiéndolo.

Si nos centramos en recientes ejemplos del marketing viral político español, sería imprescindible destacar el «no a la guerra» (Zapatero, 2003) que hizo que millones de ciudadanos que se oponían a la participación española en el conflicto iraquí comentasen a sus allegados que José Luis Rodríguez Zapatero y el PSOE no solo estaban en contra de la Guerra de Iraq, sino que incluso retirarían los efectivos militares del mismo. Los ciudadanos contra la guerra se contagiaron del efecto viral del mensaje y lo difundieron constantemente a sus amigos y conocidos. Imprescindible es también destacar que se unieron al «no a la guerra» (Zapatero, 2003) ${ }^{36}$ diversos artistas españoles de la SGAE que manejan la opinión pública con facilidad, favoreciendo al PSOE de cara a las Generales de 2004, ante lo que recibirían su correspondiente recompensa de colaboración con el famoso canon digital. El problema desde una perspectiva sociológica y

35 Vega, E. «El Mundial marca la propaganda política española». La Nueva España, p. 15, no 10.795, 19 de junio de 2014.

36 Alonso, M.A. y Adell, A. (2011). Marketing político 2.0. Barcelona: Planeta. humana no fue quien ganó las elecciones de 2004 , sino que se produjera la barbarie del 11M. Si avanzamos un poco en el tiempo y cambiamos las tornas de partido, es necesario tener en cuenta las declaraciones del principal líder de la oposición hace cuatro años cuando afirmaba que era necesario «bajar los impuestos», «no subir los impuestos» y que «subir los impuestos es más paro, más recesión, peor situación económica para las familias y las clases medias» (Rajoy, 2011). El pueblo español había rechazado rotundamente la subida del IVA del 16 al 18\% por parte del Ejecutivo socialista de Zapatero y este mensaje le convenció rotundamente, por lo que no se frenó el pueblo en propagarlo boca a oreja, como si de un virus se tratara.

Si nos centramos en recordar el Esquema Ponzi, es imprescindible darle un enfoque simbiótico junto al marketing viral político. La gran diferencia es que el marketing viral consiste en que el receptor del mensaje quede impactado en su recepción comunicativa de tal forma que no se canse en contarlo una y otra vez, no frenando en su difusión. Sin embargo, el esquema Ponzi es creado por un interesado en recibir inversiones en su firma, beneficiando a cada inversor gracias a las inversiones de los siguientes afiliados que se unen al grupo. En cambio, una vez que la gente desconfíe de esta sociedad empresarial, se destruye la pirámide y los beneficios de los inversores antiguos, salvando de ello los ingresos de su dirigente.

La perspectiva política y propagandística del marketing viral político dentro del esquema Ponzi nos confirma que los miembros de una agrupación difunden un mensaje político en representación de su partido para convencer al elector de una verdad. El centro de estrategia es difundir un mensaje populista dirigido a la 
masa, aquella que agrupe a gran parte del mercado electoral dentro de sus necesidades prioritarias y que no subdivida al pueblo en pequeños nichos o segmentos del mercado. Aquí se emplea una estrategia de penetración popular que atraiga una gran concreción de la masa y la arrastre detrás de esa gran verdad propuesta por un producto político. Ante eso el pueblo se sorprende y se alegra de ver que alguien se preocupa por las necesidades de todos los ciudadanos, recibiendo con los brazos abiertos la propuesta y tanto al partido como a su líder. Cada elector no cesará en difundir qué han dicho, quién lo ha dicho y en representación de que agrupación. Esto es una simple aplicación del marketing viral político. El problema es mucho mayor con la aplicación viral propagandística del esquema Ponzi, puesto que esa verdad es únicamente real para el representante político y su partido. Aquí el candidato ha prometido con su producto político una verdad en la que el mercado electoral invierte con su voto, confiando que será una inversión exitosa cuando vea los futuros cambios que le han prometido. El problema se da tras los comicios, cuando el pueblo ha confiado y ha invertido masivamente en ello se da cuenta a posteriori, sin posibilidad de cambio, que ha sido una promesa fantasma que no va a ser llevada a cabo por el nuevo Ejecutivo, aunque sea la agrupación en la que habían confiado y habían invertido su única opción: el voto. Es en este momento cuando el líder y su agrupación gobiernan. Y son los únicos beneficiados porque se ha desmoronado la pirámide creada por su esquema Ponzi gracias al marketing viral político, pero el pueblo no ha recibido su recompensa cuando se da cuenta que esa verdad era simplemente una mentira mil veces dicha convertida en una gran verdad.
La gran diferencia con Carlo Ponzi, Gescartera (2001), Afinsa y Fórum Filatélico (2006) es que los representantes de estas sociedades fueron encarcelados y en su caso obligados a pagar indemnizaciones a sus inversores, por publicidad engañosa. El esquema Ponzi político, nutrido gracias al marketing viral, hace posible gobernar a un partido político y a su líder, a pesar de que todos sus inversionistas, los electores, hayan sido engañados cuando se les prometía satisfacer sus principales ideas y necesidades (paro, vivienda, sanidad, educación, etc.), siendo destruida después la pirámide Ponzi, exceptuando a su líder, que gobierna por haber sabido difundir una mentira continuamente, reforzada por la vox populi, hasta que se convirtió en una gran verdad previa a las elecciones.

En referencia a los ejemplos de marketing viral político español del s. XXI, es necesario tener en cuenta la aplicación el Ponzi en el «no a la guerra» (Zapatero, 2003) que significó la retirada de los efectivos militares de Iraq para reenviarlos a Afganistán, Líbano y Libia. El «bajar los impuestos» $\mathrm{y}$ «no subir los impuestos» (Rajoy, 2011), como rechazo de la subida del IVA del $16 \%$ al $18 \%$ es otro gran ejemplo del esquema Ponzi, por la posterior subida del IVA al 21\% (2012) junto al aumento de otros impuestos. Tampoco se puede dejar de lado que Mariano Rajoy afirmaba en la oposición

La mayor facilidad que presenta desarrollar un esquema Ponzi político es cuando se funda un partido nuevo que alcanza una gran repercusión popular, pero que carece de antecedentes políticos a valorar por parte de los electores. Una nueva agrupación que desarrolle un buen marketing político, viral en este caso, y promete sanear los problemas y necesidades del pueblo es más fácil que desarrolle un Ponzi confiable para 
el mercado electoral. España cuenta a día de hoy con un nuevo partido -Podemos- que difunde un continuo mensaje político general, con acusaciones de populista y demagogo, a través de diversos medios para ganarse la aceptación de los electores. Lo más interesante es su aplicación de un marketing viral político Ponzi en los inicios del partido, cuando prometía de cara a las elecciones europeas de 2014 la «reducción de la jornada laboral a 35 horas semanales, la edad de jubilación a los 60 años» ${ }^{37}$, y otras propuestas de bases populistas como la nacionalización de la industria. El 17 de octubre Podemos anuncia que se reunirán para pactar una estrategia y un programa político definidos y viables, además de retractarse en proponer que España no pague su deuda. Eso sí, seguirán en pie las afirmaciones de Iglesias de España como «país de países, un país de naciones» ${ }^{38}$, en vez de regiones, o «Chávez es ya Bolivar, y ya cabalga como estandarte y referencia de su patria grande... Chávez es el pueblo», honrando su muerte en Fort Apache ${ }^{39}$.

No podemos dejar de lado tampoco el Ponzi desarrollado por Chávez en su primera candidatura a las Generales de Venezuela cuando este antiguo golpista neocomunista, tras su fracaso en tomar el poder por la fuerza militar en 1989, respondía el 5 de diciembre de 1998, en su entrevista del canal televisivo Univisión, a la pregunta «está usted dispuesto a entregar el poder después de cinco años» que «claro que estoy dispuesto a entregarlo, no solamente después de cinco años, incluso antes». Ante la pregunta « ¿Cuba es una dictadura o no es una dictadura?»

37 Programa electoral de Podemos (2014). Elecciones Europeas. http://podemos.info/programa/

38 El País. «El primer discurso de Pablo Iglesias como líder, en sus frases clave». El País, p. 21, no 13.650, 15 de noviembre de 2014

39 Fort Apache: Presentador: Pablo Iglesias. Fort Apache. 11 de marzo de 2013 www.youtube.com/watch? $v=e Y j \mid R 2139 r 0$ afirmaba rotundamente «Sí es una dictadura» $y$ a día de hoy ya sabemos con quién colaboraba y donde decidió pasar los últimos días de su vida. El paso del tiempo ha evidenciado que, aunque Hugo Chávez ganase las elecciones presidenciales en 1999 debido al estado de shock en el que se encontraba la economía venezolana tras su sobredosis de neoliberalismo económico, momento en el que aprovechó en desarrollar un marketing político Ponzi, no abandonó el Gobierno hasta 14 años después, cuando fallecía, dejando en el poder a su segundo (Nicolás Maduro). «Nosotros estamos dispuestos a darle facilidades, aún más de las que hay, a los capitales privados internacionales, para que vengan aquí a invertir en todo lo que es el desarrollo del país» (Chávez, 1998) $)^{40}$.

\section{El mercado electoral multinivel español}

En el caso de España es imprescindible destacar la ley D'Hondt y el sistema de circunscripciones electorales que propulsa que dicha «representación proporcional» impida que el voto de todos los españoles valga por igual. Este sistema favorece a los dos grandes partidos nacionales -PP y PSOE- y en mayor grado a los nacionalistas regionales: Amaiur, BNG, CiU, CC, EH Bildu, ERC, GBAI y PNV ${ }^{41}$. Sumémosle a esto que los comicios en España se desarrollan en un orden cronológico perfectamente determinado. En primer lugar se celebran las europeas, seguidas de las elecciones autonómicas y municipales, dando paso más tarde a las generales. Esta estructura está basada en un sistema multinivel que permi-

40 Entrevista preelectoral de Chávez en Univisión (1998) https:// www.youtube.com/watch? $v=$ YjjIR2139ro

41 Vega, E. «Las inquietudes de UPyD». El Imparcial, 18 de abril de 2015. http://www.elimparcial.es/noticia/150271/opinion/Las-inquietudesde-UPyD.html 
te a cada partido político realizar un estudio de los resultados de las europeas, seguidos de las municipales y autonómicos de cara a las más importantes para los grandes partidos: las generales. Los partidos nacionalistas regionales también se benefician de este sistema, ya que es a partir de las municipales y las autonómicas cuando podrán volcarse a obtener diputados en las cortes generales del Estado. Una vez que los ciudadanos de estas CC.AA. vean si estas agrupaciones han obtenido unos resultados notables en su C.A., evitarán recurrir al voto útil para mantener a los nacionalistas en el Congreso y el Senado.

La estructura multinivel electoral española es la que va otorgando rangos a cada uno de los representantes políticos de cada partido, quienes suelen comenzar como candidatos a las municipales. Según su actividad, desarrollo y resultados podrán ascender como representantes del partido a las autonómicas, más tarde al Congreso y finalmente al Senado ${ }^{42}$.

\section{Conclusión final}

El principal problema del pueblo en un estado democrático es cuando se transforma inconscientemente en un auténtico mercado electoral, víctima del marketing político. Con esto me es- toy refiriendo a que el ciudadano escoge un partido político y no un tipo de gobierno, potenciando una partitocracia. Este problema se desarrolla por una herencia familiar y un entorno propio que le indica qué partido ha de votar, sin preocuparle propuesta alguna del partido y sus representantes. Además de esto, el ciudadano no contrasta la información política ofertada por los media, los cuales presentan una conocida tendencia política o de partido, llegando a potenciar un sectarismo de partido que convierte al elector en súbdito de un partido político.

Un gran problema de España respecto a su significado democrático es que es una de las democracias más jóvenes de la Europa Occidental, lo que implica un desarrollo menos evolutivo, pero habemos de evolucionar en esta materia para dejar de caer víctimas bajo un marketing viral político dentro del esquema Ponzi que haga que los votantes inviertan su voto en una formación política que promete algo y desarrolla otra cosa a posteriori.

El esquema Ponzi político es la mejora de la «mentira mil veces dicha se convierte en una gran verdad» de Goebbels y las habilidades para difundir esa mentira que arraigue hábilmente en el elector. Una mentira que, una vez descubierta no será retractada como tal en el futuro gobierno. 


\section{Bibliografía}

Alonso, M.A. y Adell, A. (2011). Marketing político 2.0. Barcelona: Planeta.

Aróstegui, J. (2003). Ha del mundo contemporáneo. Barcelona: Vicens Vives

Arvedlund, E (2009). Madoff. The man who stole $\$ 65$ billion. London: Penguin group.

Bermudo, J.M. (1994). Maquiavelo, consejero de príncipes. Barcelona: Universidad de Barcelona.

Bruno, G. (2002). Marketing multinivel 3x. Roma: Bruno Editore.

Clothier, P. (1991). Marketing multinivel. El negocio de los 90. Valencia: Jumerca.

Connolly, M. (2007). International business finance. Nueva York: Routledge.

Ferrer, A. (2010). Marx. Leyendo el manifiesto del partido comunista (1848). Valencia: PUV.

Ferrer, E. (1992). De la lucha de clases a la lucha de frases. México D.F: Aguilar.

Gallego, F. y Morente, F. (2005). El fascismo en España. Barcelona: Intervención cultural.

García, J. (2008). De la quimera inmobiliaria al colapso financiero. Barcelona: Bosch.

García, M.C. (2014). Nuevas perspectivas del tratamiento jurídico de la discapacidad y la dependencia. Madrid: Dykinson.

García, M.D. (2004). Marketing multinivel. Madrid: Esic.

García-Uceda, M. (2011). Las claves de la publicidad. Madrid: Esic.

Gramsci, A. (1979). Note sul Machiavelli, sulla politica, e sullo stato moderno. Milán: Einaudi.

Kiyosaki, R. (2012). La ventaja del ganador. Madrid: Aguilar.

Kotler, P. (2003). Fundamentos de marketing. México D.F: Prentice Hall.

Licciardello, S. (2001). MLM Success secrets. Nueva York: Routledge.
Molins, J. y Oñate, P (2009). Elecciones y comportamiento electoral en la España multinivel. Madrid: CIS.

Montañés, M.A. (2014). Técnicas de Marketing viral. Madrid. Esic.

Munuera, J.L. y Rodríguez, A.I. (2007). Estrategias de marketing. Madrid: Esic.

Ohanian, P.C. (2010). La cuestión armenia y las relaciones internacionales. Buenos Aires: Akian.

Ongallo, C. (2007). El libro de la venta directa. Madrid: Díaz de Santos

Ongallo, C. (2012). Otros campos de la venta directa. Madrid: Díaz de Santos

Pineda Cachero, A. (2006). Elementos para una teoría comunicacional de la propaganda. Sevilla: Alfar.

Pizarroso, A. (2005). Nuevas guerras, vieja propaganda. Madrid: Cátedra.

Reyes, R. y Munch, L. (2012). Comunicación y mercadotecnia política. México D.F: Noriega

Rivera, J. y Sutil, L. (2004). Marketing y publicidad subliminal. Madrid: Esic.

Rothberg, M. (2010). American Greed. Bloomington: Author House.

Ruiz Ocampo, A. (1999). El Consejo Nacional de la Publicidad: origen, estructura y trayectoria. México D.F: Plaza y Valdés.

Sander, P.J. (2009). Madoff. Plymouth: Lyons Press.

Sivera, S. (2008). Marketing viral. Barcelona: Editorial UOC. Schuster, G. (2010). Network marketing. Nordersted (Alemania): Grin.

Teall, J. (2013). Financial trading and investment. Oxford: Academic Press.

Weitz, E.D. (2009). La Alemania de Weimar. Presagio y Tragedia. Madrid: Turner. 


\section{Prensa}

Agencias. «El asesino de Oslo dice que organizó junto a dos células los ataques». Público, p. 8, no 1.387, 25 de julio de 2011.

Amil, G. «Mostachos solidarios». Diario de Sevilla, p. 17, nº 9.724, 20 de noviembre de 2013.

Editorial. «El primer discurso de Pablo Iglesias como líder, en sus frases clave». El País, p. 21, nº 13.650, 15 de noviembre de 2014

Luengo, M. «¿A dónde va a parar el dinero de Movember?». El País, p. 17, no 13.647, 12 de noviembre de 2014.

Vega, E. «El Mundial marca la propaganda política española». La Nueva España, p. 15, n 11.824, 19 de junio de 2014. Vega, E. «Las inquietudes de UPyD». El Imparcial, 18 de abril de 2015 .

http://www.elimparcial.es/noticia/150271/opinion/Las-inquietudes-de-UPyD.html

\section{Televisivas}

La Sexta Noche. Presentador: Iñaki López. La Sexta. 24 de julio de 2006.

\section{Electrónicas}

Programa electoral de Podemos (2014). Elecciones Europeas. http://podemos.info/programa/

Sistema Bolivariano de Comunicación e Información

http://www.vive.gob.ve/blogs/frases-de-ch\%C3\%Alvez/ discurso-del-presidente-de- la- rep\%C3\%BAblica-bolivariana-de-venezuela- hugo-ch\%C3\%Alvez

Fort Apache: Presentador: Pablo Iglesias. Fort Apache. 11 de marzo de 2013 www.youtube.com/watch?v=eYj1R2139r0 Entrevista preelectoral de Chávez en Univisión (1998) https://www.youtube.com/watch?v=eYjlR2139r0+ J.C. Monedero 